Biological and Applied Sciences

Vol.60: e17160466, January-December 2017 http://dx.doi.org/10.1590/1678-4324-2017160466 ISSN 1678-4324 Online Edition

\title{
Detection of Genetic Relationship in the Tree of Life of Some Quail Through Molecular Markers Analyses
}

\author{
Lamiaa Elsayed Mokhtar Deef ${ }^{1} *$. \\ ${ }^{1}$ Department of Zoology, Faculty of Science, Damietta University, New Damietta, Damietta, Egypt.
}

\begin{abstract}
Quail is an important and interesting group of galliform birds. The Common quail (Coturnix coturnix); the Japanese quail (Coturnix japonica); the Panda quail (Coturnix japonica); the Dotted white quail (Coturnix japonica) and the Bobwhite quail (Colinus virginianus) were used in this study. PCR-RFLP and SDS-proteins were performed to reveal the genetic characterization and genetic relationship of the studied quails. Analysis of fragments generated by digestion of PCR product with restriction enzyme NlaIII recorded highly polymorphic restriction profiles. There is a wide intraspecific COI, SEMA3E and TLX genes variability among the studied quails. Protein bands varied from10 to 18 between quails with minimum number of bands were in the Dotted white quail (10 bands) and the maximum were in the Japanese quail (18 bands) as measured by SDS-polyacrylamide gel electrophoresis. The Dotted white quail revealed the lowest similarity to the Bobwhite with a coefficient of 0.18 while The similarity coefficients between the Common quail and each one of the other quails were 0.67, 0.62, 0.45 and 0.42 for the Japanese, Panda, Dotted white and the Bobwhite quails, respectively. The results indicate that, PCR-RFLP and protein analyses are good techniques to evaluate genetic characterization and genetic relationship of these quails.
\end{abstract}

Key words: birds; PCR; quail; SDS-PAGE; Galliformes

\footnotetext{
*Author for correspondence: lamiaadeef@ yahoo.com
} 


\section{INTRODUCTION}

Presently, quail gained a great attention due to its importance to society and value as food animal and model systems. It well known that, the Japanese quail (Coturnix japonica) is different from the Common quail (Coturnix coturnix) ${ }^{1,2}$ while, the Panda and the Dotted white quails are known as mutant plumage colors of the Japanese quail (Coturnix japonica) ${ }^{3}$ but all of these species belong to the family Phasianidae and genus Coturnix. Although the Bobwhite quail (Colinus virginianus) is one of the species of the same order Galliformes, but it belongs to the family Odontophoridae and genus Colinus. This similarity between some studied species and the difference between the others led to be motivated to use some molecular biology techniques to study the genetic relationship among these species.

Protein marker as Sodium dodecyl sulfate polyacrylamide gel electrophoresis (SDSPAGE) is widely used for identification, since it offers the advantage to have a good level of taxonomic resolution at species and subspecies ${ }^{4}$. In addition to SDS-PAGE marker, application of DNA markers is finding wide acceptance in species and population genetics. With DNA markers, it is possible to exploit genetic variation in the entire genome. Both genomic and mitochondrial DNA is used for varied applications. Restriction fragment length polymorphism (RFLP) is a commonly technique used in differentiation between species and subspecies by analysis of patterns derived from cleavage of their DNA. Cytochrome oxidase I (COI) is a mitocondrial (mt) gene with an evolution rate smaller than that observed for mtDNA and its amino acid sequence is highly conserved across phyla. Molecular tools, using mtDNA COI region, have been used in several genetic studies $5,6,7,8,9$. The SEMA3E gene encodes a secreted class 3 semaphorin that triggers repulsion of endothelial cells in specific vascular beds and modulates axonal growth and synaptic connectivity for the correct wiring of the CNS ${ }^{10}$ will be used in this work. Moreover, Song et al. ${ }^{11}$ reported that TLX is an important target in neural development by regulating cell cycle progression in NSCs (Neural Stem Cells) by recruiting histone deacetylases, this gene will be used. In light of this, the aim of this study was to investigate the genetic relationship between these different quails using PCR-RFLP and SDS-proteins techniques.

\section{MATERIALS AND METHODS}

\section{Experimental birds}

Fifty birds were used in this study; belong to one order (Galliformes) and two families. Migratory or the Common quail (Coturnix coturnix) $(\mathrm{n}=10)$; the Japanese quail (Coturnix japonica) $(\mathrm{n}=10)$; the Panda quail (Coturnix japonica) $(\mathrm{n}=10)$; the Dotted white quail (Coturnix japonica) $(\mathrm{n}=10)$ represent family Phasianidae and the Bobwhite quail (Colinus virginianus) $(\mathrm{n}=10)$ represent family Odontophoridae. Birds (males in 7 weeks age) were obtained on the local markets and then taken to the lab for dissection. Samples of different tissues were taken and immediately frozen at $80^{\circ} \mathrm{C}$.

\section{SDS-Protein}

SDS-polyacrylamide gel electrophoresis was performed in $14 \%$ acrylamide slab gels following the system of Laemmli ${ }^{12}$. Protein extraction was conducted by homogenizing $1.0 \mathrm{~g}$ of tissue in $2 \mathrm{ml}$ saline solution $\mathrm{NaCl}(0.9 \%)$ using a manual homogenizer. Samples were centrifuged at $5000 \mathrm{rpm}$ for $10 \mathrm{~min}$. The supernatants that contain protein extract were kept deep-frozen until use for electrophoresis analysis. A volume of $20 \mu \mathrm{l}$ protein extract was added to $10 \mu \mathrm{l}$ of treatment buffer. 
$20 \mu \mathrm{l}$ of the mixture was loaded in the gel. After electrophoresis, the gel was stained by commassie brilliant blue. The gel was destained after the appearance of bands and photographed.

\section{PCR - RFLP analysis \\ DNA extraction}

Tissue samples $(10 \mathrm{mg})$ were taken from each quail and DNA was isolated as described in Aljanabi and Martinez ${ }^{13}$ and modification by Hassab El-Nabi and Elhassaneen ${ }^{14}$.

\section{PCR-RFLP Primers}

Four primers were used in this study, the code and sequences of these primers are shown in table (1).

Table 1: primers and primer sequences used for amplification and sequencing in this study.

\begin{tabular}{|c|c|c|c|c|}
\hline No. & Primer code & $\begin{array}{l}\text { Gene } \\
\text { name }\end{array}$ & Nucleotide sequence (5' to 3 ) & $\begin{array}{l}\text { Annealing } \\
\text { temp. }{ }^{\circ} \mathbf{C}\end{array}$ \\
\hline \multirow[t]{2}{*}{1} & \multirow[t]{2}{*}{$\mathrm{P} 1$} & \multirow[t]{2}{*}{ SEMA3E } & Forward-ATACTCCAGCTGAGTGGGGA & \multirow[t]{2}{*}{60} \\
\hline & & & Reverse-CAGAAGTATGAGGGAGATCAG & \\
\hline \multirow[t]{2}{*}{2} & \multirow[t]{2}{*}{$\mathrm{P} 2$} & \multirow[t]{2}{*}{ TLX } & Forward-ACACTAGGAACATAATGGGCT & \multirow[t]{2}{*}{57} \\
\hline & & & Reverse-TCACTGTGGCGTTTCAGATT & \\
\hline \multirow[t]{2}{*}{3} & \multirow[t]{2}{*}{ P3 } & \multirow[t]{2}{*}{ COI } & Forward-TTCTCCAACCACAAAGACATTGGCAC & \multirow[t]{2}{*}{58} \\
\hline & & & Reverse-ACGTGGGAGATAATTCCAAATCCTG & \\
\hline \multirow[t]{2}{*}{4} & \multirow[t]{2}{*}{$\mathrm{P} 4$} & \multirow[t]{2}{*}{ COI } & Forward- CGAATGAATAACATAAGCTT & \multirow[t]{2}{*}{59} \\
\hline & & & Reverse- CC TCC TGCAG GGTCGAAGAA & \\
\hline
\end{tabular}

\section{PCR-RFLP and digestion with NlaIII}

Polymerize chain reactions for species were performed in a final volume of $25 \mu 1$ and contained $10 \mu \mathrm{L}$ PCR buffer, $1 \mu \mathrm{l}$ dNTP, $0.5 \mu \mathrm{l}$ of each primer, $0.5 \mu \mathrm{l} \mathrm{Taq}$ DNA Polymerase (1.25 unit) and $0.5 \mu 1$ (50 ng) genomic DNA. The thermal profile included an initial denaturation step of $94^{\circ} \mathrm{C}$ for $5 \mathrm{~min}$, followed by 32 cycles of 94 ${ }^{\circ} \mathrm{C}$ for $1 \mathrm{~min}$, annealing at the corresponding specific temperature (Table 1) for 1 min, and $72{ }^{\circ} \mathrm{C}$ for $1 \mathrm{~min}$. A final extension step of $72{ }^{\circ} \mathrm{C}$ for $10 \mathrm{~min}$ concluded the profile. The restriction enzyme NlaIII digests were performed in a final volume of $30 \mu \mathrm{l}$ and contained $10 \mu \mathrm{l} \mathrm{COI} \mathrm{PCR} \mathrm{product,} 2 \mu \mathrm{l}$ Buffer, $17 \mu \mathrm{l}$ dist. water and 1.0 $\mu \mathrm{l}$ NlaIII. Digests were incubated at $37{ }^{\circ} \mathrm{C}$ for $1 \mathrm{~h}$, then electrophoresed in $2 \%$ agarose gels (sodium boric acid buffer system) and stained with ethidium bromide for visualization.

\section{Statistics}

Molecular weight of protein in electrophoregrams and coefficients of similarity (Jaccard coefficient) were calculated.

$\mathrm{S}_{\mathrm{ab}}=\mathrm{N}_{\mathrm{s}} / \mathrm{N}_{\mathrm{s}}+\mathrm{N}_{\mathrm{d}}$ 
$\mathrm{S}_{\mathrm{ab}}$ : coefficients of similarity between two strains (a) and (b). $\mathrm{N}_{\mathrm{s}}$ : Number of proteins having similar molecular weight between two strains (a) and (b) in electrophoregram. $\mathrm{N}_{\mathrm{d}}$ : Number of proteins having different molecular weight between two strains (a) and (b) in electrophoregram ${ }^{4}$.

The SDS-PAGE bands were recorded according to the presence (1) or absence (0) of a protein band at the same location on the gel. On the other hand, the PCR-RFLP bands were recorded by the same method. The data were statistically analyzed in each one of SDS-PAGE and PCR-RFLP methods by the software program NTSYSpc 2.02e (Numerical Taxonomy and Multivariate Analysis System) ${ }^{15}$. The genetic relationship among cultivars was calculated using the similarity coefficient of Nei and $\mathrm{Li}^{16}$. Dendrogram was constructed by Unweighted Pair Group Method with Arithmetic Averages (UPGMA) cluster analysis.

\section{RESULTS}

\section{SDS-Protein}

The number of protein bands that were obtained from this study varied among birds. A range of 10 to 18 bands were recognized in the pattern of the studied quail with minimum value in the Dotted white quail (10 bands) and the maximum was in the Japanese quail (18 bands) (Fig. 1). The molecular weights of these bands showed a wide range between a maximum of $240 \mathrm{kDa}$ and a minimum of $12 \mathrm{kDa}$. All the samples recorded two shared bands with a molecular weight of 13 and $100 \mathrm{kDa}$. There were no shared bands between the studied quail at the extremes of the protein profile. The numbers of shared bands were 10,12, 12, 14 and 18 within the Dotted white, the Common, the Bobwhite and the Japanese quail species, respectively. When the different localities were compared, the shared bands were 10 between the Common and the Japanese quail, 8 between the Common and the Panda quail, 7 between the Common and the Dotted white quail, 5 between the Common and the Bobwhite quail, 14 and 10 between the Japanese and both of the Panda and the Dotted white quail respectively, 6 between the Japanese and the Bobwhite species, 3 between the Bobwhite and the Panda quail and 2 between the Bobwhite and the Dotted white quail. Six unique bands were found in the Bobwhite, and no unique bands found in the Dotted white and the Panda quail; two unique bands were shown in the Common quail, and one unique band was found in the Japanese quail. The Japanese quail recorded the highest similarity to the Panda quail with a coefficient of 0.88 and to the Dotted white with a coefficient of 0.71 . The Dotted white quail revealed the lowest similarity to the Bobwhite with a coefficient of 0.18 . The similarity coefficients between the Common and each of the four other quail were 0.67, 0.62, 0.45 and 0.42 for the Japanese, Panda, Dotted white and Bobwhite quails, respectively (Table 2). 


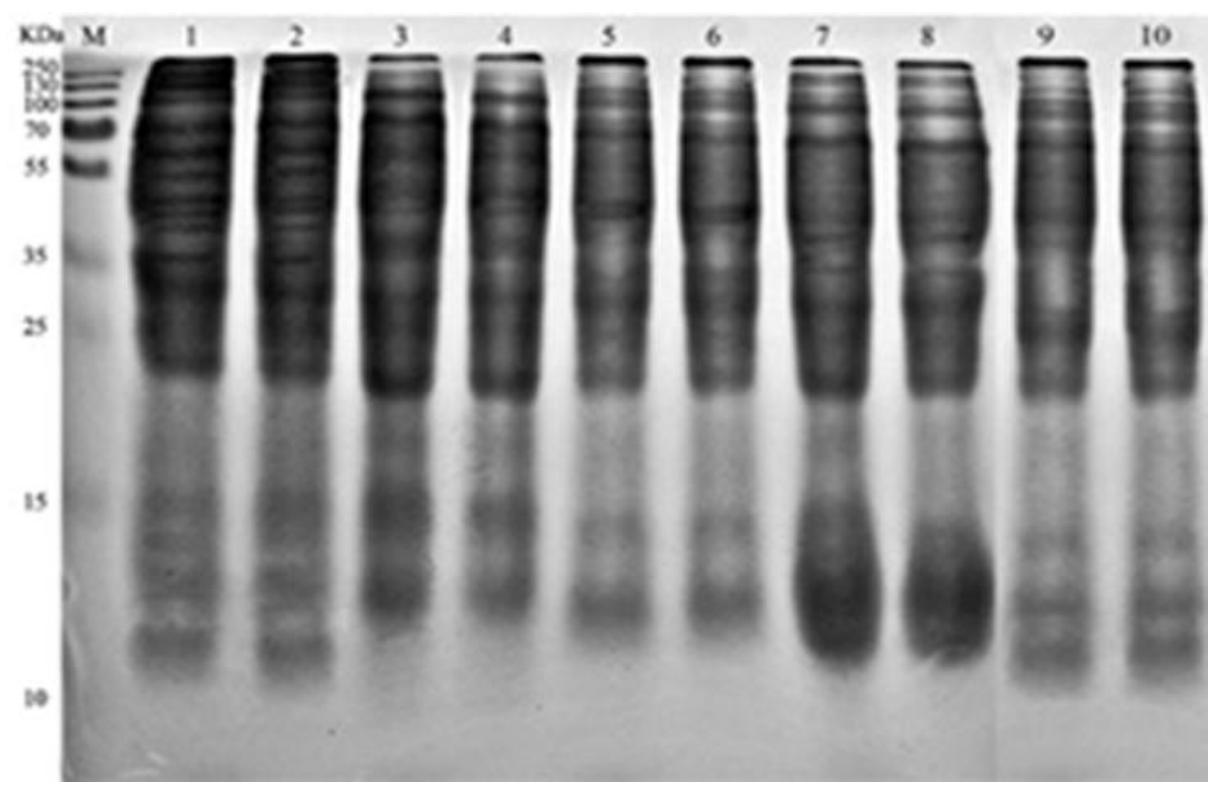

Fig. 1: Protein profile of SDS - PAGE: $M=$ Molecular marker, Lanes 1 and 2 are the Japanese quail (Coturnix japonica), Lanes 3 and 4 are the Bobwhite quail (Colinus virginianus), Lanes 5 and 6 are the Common quail (Coturnix coturnix), Lanes 7 and 8 are the Panda quail (Coturnix japonica) and Lanes 9 and 10 are the Dotted white quail (Coturnix japonica).

Table 2. The estimated similarity coefficients calculated according to the shared protein bands among the studied quail species.

\begin{tabular}{|c|c|c|c|c|c|}
\hline & Common & Japanese & Panda & Dotted white & Bobwhite \\
\hline Common & 0 & & & & \\
\hline Japanese & 0.67 & 0 & & & \\
\hline Panda & 0.62 & 0.88 & 0 & & \\
\hline Dotted white & 0.45 & 0.71 & 0.83 & 0 & \\
\hline Bobwhite & 0.42 & 0.40 & 0.23 & 0.18 & 0 \\
\hline
\end{tabular}

\section{PCR-RFLP}

The electrophoresis analysis of PCR amplification of quails showed DNA fragments with size of approximately 412 base pairs (bp) as dominant PCR product for primer P1. Meanwhile, the electrophoresis of digestion product of PCR fragment with the restriction enzyme revealed two fragments; $150 \mathrm{bp}$ and $262 \mathrm{bp}$ in the Common quail and in the Japanese quail two fragments were obtained, of $70 \mathrm{bp}$ and $342 \mathrm{bp}$. In addition, performed digestion with NlaIII of Panda quail obtained the restriction band patterns of two fragments of $120 \mathrm{bp}$ and $292 \mathrm{bp}$. Also, two fragments of $90 \mathrm{bp}$ and $322 \mathrm{bp}$ characterize the restriction profile of the Dotted white quail. On the other hand, a different restriction profile with one fragment in the Bobwhite quail of 412 bp with no digestion of restriction enzyme occur (Fig. 2A).

In the current study, a single amplification product of approximately 546 bp for primer P2 in each quail was obtained. The Common quail was characterized by three fragments, of $100 \mathrm{bp}, 180 \mathrm{bp}$ and $266 \mathrm{bp}$ instead in the Japanese and the Panda quails obtained three fragments, of $120 \mathrm{bp}, 180 \mathrm{bp}$ and $246 \mathrm{bp}$. Also, in the Dotted white quail gave three fragments; $70 \mathrm{bp}, 180 \mathrm{bp}$ and $276 \mathrm{bp}$ while, only two fragments of $140 \mathrm{bp}$ and $416 \mathrm{bp}$ characterize restriction profile of the Bobwhite quail (Fig. 2B).

For primer P3, a single amplification product of approximately $677 \mathrm{bp}$ in each quail was obtained. Digestion of this fragment with NlaIII produced three fragments in the Common quail, of $70 \mathrm{bp}, 120 \mathrm{bp}$ and $487 \mathrm{bp}$. In the Japanese and the Dotted white quails, three fragments were obtained; $70 \mathrm{bp}, 130 \mathrm{bp}$ and $477 \mathrm{bp}$ in each quail. On 
the other hand, no digestion with the enzyme occurs in the Bobwhite quail and only one fragment of 677 bp characterizes restriction profile (Fig. 2C). No PCR product occurs with the studied quail in primer P4.
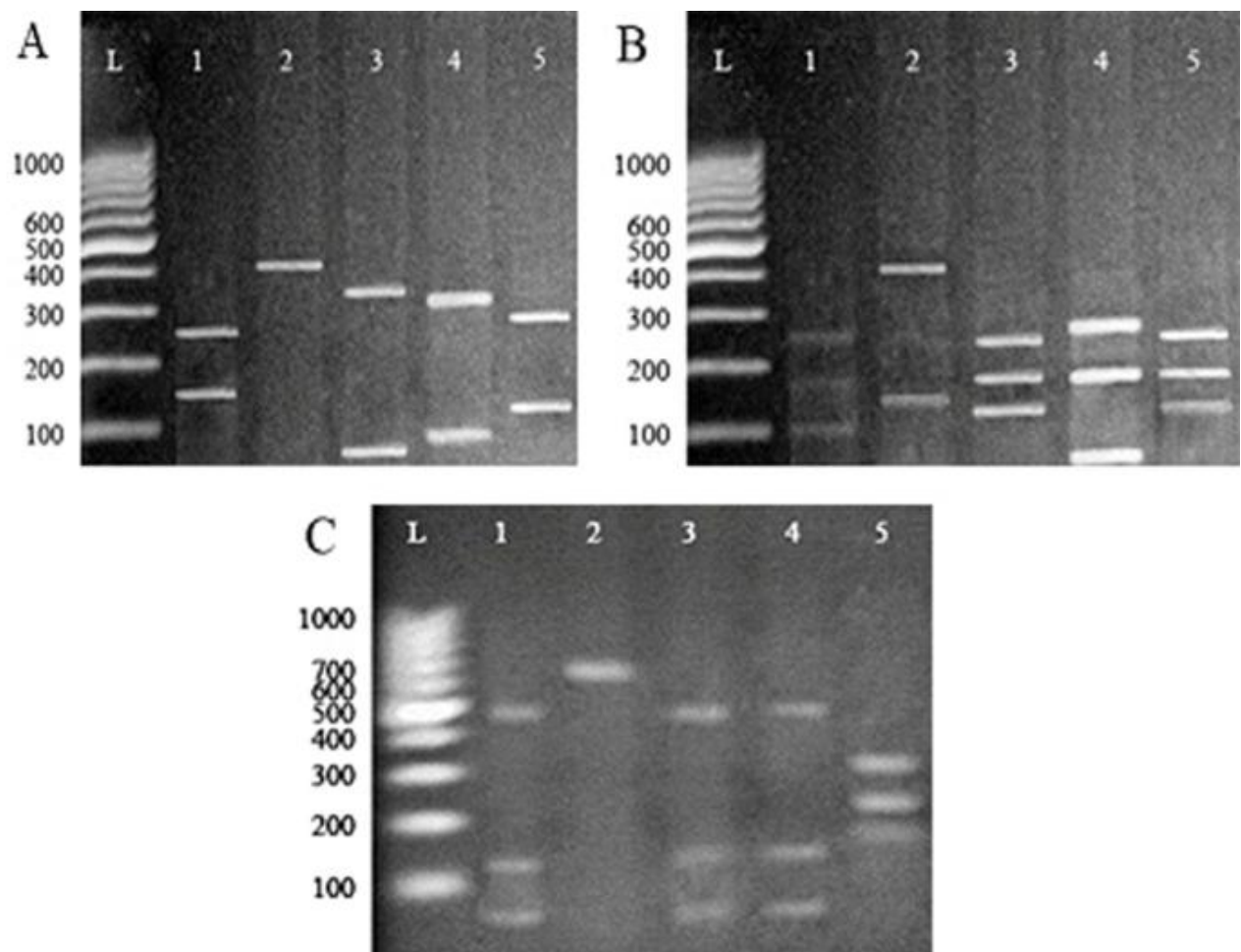

Fig. 2: Polymerase chain reaction based restriction fragment length polymorphism profiles of mitochondrial A: SEMA3E (gene encodes a secreted class 3 semaphorin) primer P1, B: TLX (gene encodes a nucleus class nuclear receptor subfamily 2 group E member 1) primer P2 and C: COI (cytochrome c-oxidase subunit I genes) primer P3 of quails digested with restriction endonuclease NlaIII. Lane L: DNA marker, lane 1: the Common quail (Coturnix coturnix), lane 2: the Bobwhite quail (Colinus virginianus), lane 3: the Japanese quail (Coturnix japonica), lane 4: the Dotted white quail (Coturnix japonica) and lane 5: the Panda quail (Coturnix japonica).

\section{Genetic relationship and phylogenetic tree}

A neighbor-joining tree based on Nei's unbiased genetic distance matrices revealed that the Japanese quail was most closely related to the Panda quail. The Common quail fall also in the same clade of two previous quails, and closely related to the Japanese quail than to the Panda quail. On the other hand, the Bobwhite quail was in a separate group with a node connected to the other studied quails. In addition, in the constructed dendrogram, there are two separate genetic groups; one group formed by the Bobwhite quail and the other group formed by the Common, Japanese, Panda and Dotted white quails (Fig. 3A, B).

\section{DISCUSSION}

Weber et al. ${ }^{17}$ reported that, the sodium dodecyl sulfate polyacrylamide gel electrophoresis (SDS-PAGE) technique was a powerful tool for estimating the molecular weights of proteins. In the present study, the electrophoretic banding of proteins revealed the studied quails have similar bands within the molecular weight of the range between 100 and $70 \mathrm{kDa}$ and in the range between 45 and $13 \mathrm{kDa}$. Similarly, in the study by Metcalf et al. ${ }^{18}$, in which the former range is comparable to vertebrate albumin $(65-70 \mathrm{kDa})$ considered SDS-PAGE as a good indicator for species differentiation. Therefore, these similarities could be considered as an 
Genetic relationship in the tree of life of quail

indication of gene flow among the studied samples and do not refer to any fragmentation ${ }^{19}$.

Furthermore, the amplification of part of mt DNA-COI region was successfully used in the study, followed by its digestion with restriction enzyme. The analysis of generated fragments (RFLP) showed a great genetic variation between the Common, Japanese, Panda, Dotted white and Bobwhite quails in this work. The results agreed with Casiraghi et al. ${ }^{20}$ where the enzyme NlaIII digestion produced highly polymorphic intraspecific and interespecific restriction profiles indicating that this enables the differentiation between these quails and that there is a wide intraspecific COI, SEMA3E and TLX variability among studied quails where this enzyme produced restriction fragments in some quails and did not show any fragments in the other quail. This differentiation may be providing essential information for use, collection, conservation and research of the entail genetic resources.

The phylogenetic tree constructed from PCR-RFLP and protein analysis data suggested that the Japanese and the Panda quail were sufficiently genetically similar to each other. Also, such tree revealed the Bobwhite quail may be particularly valuable as a source of genetic variability because it is close to the root of the phylogenetic tree. The findings of this results indicated that, the Bobwhite quail should be classified as being not genetically close to these other studied quails; also showed that, the Japanese quail and the Panda quail were related to the Common quail and fall genetically far from the Bobwhite quail which is clearly distinct from these quails.

The branching diagrams or dendrograms also showed, clustering of the Common, Japanese, Panda, Dotted white and Bobwhite quails. The Bobwhite quail came basal in the dendrogram since it showed the lowest similarities to the all quails. The application of the UPGMA clustering on the raw data obtained from SDS proteins split the phylogenetic tree into two main clusters: the cluster of the Common, Japanese, Panda, Dotted white quails as one group and the cluster of the Bobwhite quail as another group. By comparing this tree to that of Figure $3(\mathrm{~A}, \mathrm{~B})$, it was obvious that there was a concordance regarding the kinship of the studied quails.
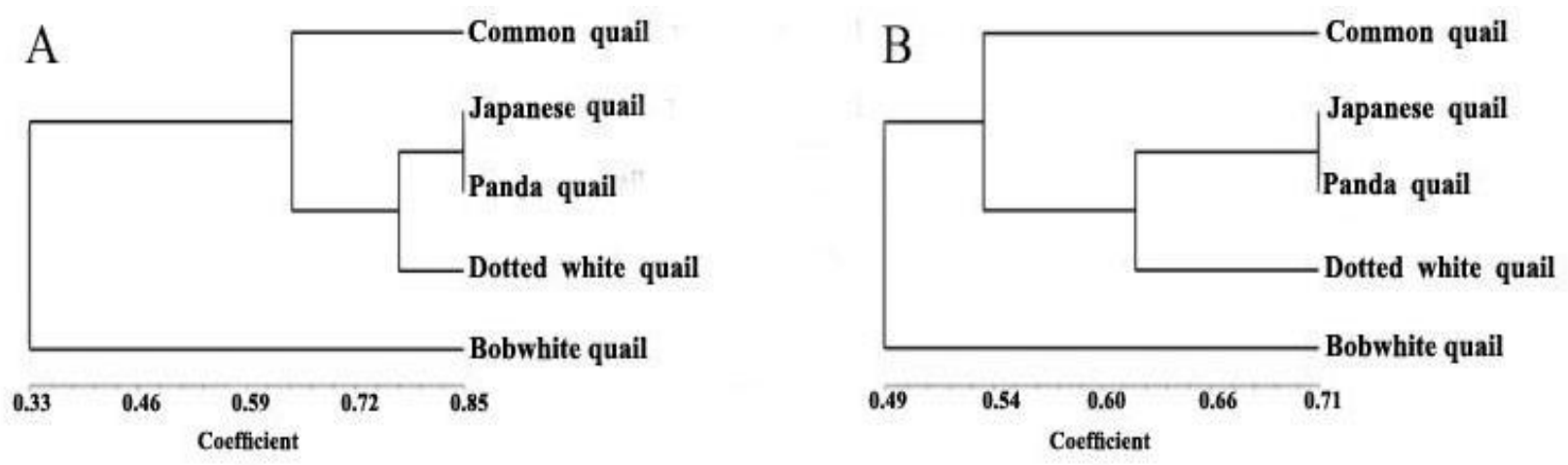

Fig. 3: Dendrogram constructed using UPGMA cluster analysis from NTSYSpc software of A: Protein and B: restriction fragment length of five studied quails.

\section{CONCLUSION}

This study was the first differentiation between the studied quails by using these molecular techniques. The information generated in this study will greatly aid in the genetic differentiation and relationship of the different quails. Furthermore, it was confirmed through the present study that the PCR-RFLP and protein techniques are a useful tools to evaluate genetic variation within and between quails. 


\section{REFERENCES}

1-Mizutani M. The Japanese quail, Laboratory Animal Research Station, Nippon Institute for Biological Science. Kobuchizawa, Yamanashi, Japan, 408-0041; 2003. Pp. 143-163.

2-Hassan SM, Mady ME, Cartwright AL, Sabri HM, Mobarak MS. Effect of acetyl salicylic acid in drinking water on reproductive performance of Japanese quail (Coturnix coturnix japonica). Poult Sci. 2003; 82: 1174-1180.

3-Tsudzuki M, Kusano S, Wakasugi N, Morioka H, Esaki K. Dotted white - a plumage colour mutant in Japanese quail (Coturnix coturnix japonica). Jikken Dobutsu. 1992; 41: 25-31.

4-Ghazi F, Henni DE, Benmechernene Z, Kihal M. Phenotypic and Whole Cell Protein Analysis by SDS-PAGE for Identification of Dominants Lactic Acid Bacteria Isolated from Algerian Raw Milk. World J Dairy Food Sci. 2009; 4(1): 78-87.

5-Lovette IJ, Bermingham E, Rohwer S, Wood C. Mitochondrial restriction fragment length polymorphim (RFLP) and sequence variation among closely related avian species and the genetic characterization of hibrid Dendroica warbler. Mol Ecol. 1999; 8: 1431-1441.

6-Matsumoto M, Hayami I. Phylogenetic analysis of the family Pectinidae (Bivalvia) based on mitochondrial cytochrome C oxidase subunit I. J Moll Stud. 2000; 66: 477-488.

7-Kurabayashi A, Ueshima R. Complete sequence of mitochondrial DNA of the primitive Opistobranch Gastropod Pupa strigosa: Systematic implications of the genome organization. Mol Biol Evol. 2000; 17: 266-277.

8-Campbell G, Jones CS, Lockyer AE, Hughes S, Brown D, Noble LR, Rollinson D. Molecular evidence supports an African affinity of the Neotropical freshwater gastropod, Biomphalaria glabrata, Say 1818, an intermediate host for Schistosoma mansoni. Proc R Soc Lond B. 2000; 267: 2351-2358.

9-Deef LEM, Hassab El-Nabi SE. Genetic characterization of Red Junglefowl (Gallus gallus gallus) and commercial chicken lines (Gallus gallus domesticus) using molecular markers. Int J Adv Res. 2015; 3(10): 1763- 1769.

10- Cariboni A, André V, Chauvet S, Cassatella D, Davidson K, Caramello A, Fantin A, Bouloux P, Mann F, Ruhrberg C. Dysfunctional SEMA3E signaling underlies gonadotropin-releasing hormone neuron deficiency in Kallmann syndrome. J Clin Invest. 2015; 125(6): 2413-2428.

11- Song J, Cho KJ, Oh Y, Lee JE. Let7a involves in neural stem cell differentiation relating with TLX level. Biochem Biophys Res Commun. 2015; 462: 396-401.

12- Laemmli UK. Cleavage of structural proteins during assembly of head bacteriophage $\mathrm{T}_{4}$. Nature 1970; 227: 680-685.

13- Aljanabi SM, Martinez I. Universal and rapid salt-extraction of high quality genomic DNA for PCR-based techniques. Nuc Acids Res. 1997; 25: 4692 - 4693.

14- Hassab El-Nabi SE, Elhassaneen YA. Detection of DNA damage, molecular apoptosis and production of home-made ladder by using simple techniques. Biotechnol. 2008; 7(3): $514-522$.

15- Rohlf FJ. NTSYSpc: Numerical Taxonomy and Multivariate Analysis System version 2.02 Exeter Software, Setauket, NY; 1997.

16- Nei M, Li WH. Mathematical model for studying genetic variation in terms of restriction endonucleases. Proc Nat Acad Sci USA. 1979; 76: 5296-5273.

17- Weber K, Pringle JR, Osborn M. Measurement of molecular weights by electrophoresis on SDS Acrylamide Gel. Methods Enzymol. 1971; 26: 3-27.

18- Metcalf VJ, Bernnan SO, Chambers GK, George PM. The albumin of the brown trout (Salmo trutta) is a glycoprotein. Biochemica et Biophysica Acta 1998; 1386: 90-96.

19- Ferguson A. Biochemical systematics and evolution. Glasgow and London, Blakie; 1980.

20- Casiraghi M, Anderson TJ, Bandi C, Bazzocchi C, Genchi C. A phylogenetic analysis of filarial nematodes: comparison with the phylogeny of Wolbachia endosymbionts. Parasitol 2001; 1: 93-103. 